Received

10 Desember 2018
Revisied

20 Februari 2019
Acceptep

16 Juni 2019

\title{
HUBUNGAN ANTARA SELF MANAGEMENT DAN KUALITAS HIDUP PASIEN DIABETES MELITUS TYPE 2
}

\author{
Dewi Murdiyanti Prihatin Putri \\ Akper "YKY" Yogyakarta \\ Email : dewiputri4377@gmail.com
}

\begin{abstract}
ABSTRAK
Latar Belakang : Diabetes Melitus (DM) Tipe 2 merupakan salah satu penyakit metabolik yang bersifat kronik yang ditandai dengan hiperglikemia yaitu peningkatan gula darah yang disebabkan adanya kelainan sekresi insulin, resistensi insulin atau keduanya dan dapat mengakibatkan kerusakan jangka panjang serta disfungsi atau kegagalan pada beberapa organ tubuh (Soegondo, 2013). Program yang diselenggarakan oleh BPJS Kesehatan ini bertujuan untuk mendorong peserta penyandang penyakit kronis dapat mengelola kesehatan (self management) untuk mencapai kualitas hidup optimal. Salah satu penyakit kronis yang dikelola adalah Diabetes Melitus Tipe 2. Tujuan : Tujuan dari penelitian ini untuk mengetahui hubungan antara Self Management dengan Kualitas Hidup Pasien Diabetes Melitus Type 2 di Dusun Sonosewu Kasihan Bantul Yogyakarta. Metode : Jenis penelitian deskriptif korelasi dengan metode yang digunakan adalah crossectional. Hasil : Hasil penelitian ini adalah ada hubungan yang signifikan antara self management dan kualitas hidup pasien DM Tipe 2 dengan dibuktikan $\mathrm{p}$ value $=0,002(<0,05)$ dan nilai koefisien korelasi sebesar 0,494.
\end{abstract}

Kata Kunci : Diabetes Melitus Tipe 2, self management, kualitas hidup.

\section{ABSTRACT}

Background : Tyoe 2 Diabetes Mellitus (DM) is achronic metabolic disease characterized by hyperglycemia, which is in an increase in blood glucose caused by abnormalities in insulin secretion, insulin resistance or both and can cause long term damage and dysfunction or failure in several organs (Soegondo, 2013). The program organized by BPJS Kesehatan aims to encourage partipants with chronic illness to manage health (self management) to achive optimal quality of life. One of the chronic diseases that are managed type 2 Diabetes Mellitus. Objektive: The purpose of this study is to determine the raltionship between self management and quality of life of Type 2 Diabetes Mellitus Patients in Sonosewu Bantul Yogyakarta. Methode: This study is descritive correlation research with cross-sectional method Result : The results of this study are that there is a significant relationship between self management and teh quality of life of patients with type 2 Dibetes Mellitus with p value =0,002 (<0,005) and a correlation coeficient of 0,494.

Keywords : Type 2 Diabetes Mellitus, self management, quality of life 


\section{PENDAHULUAN}

Gangguan kelenjar endokrin ini paling banyak terjadi pada kelenjar pancreas yang memunculkan penyakit diabetes dan $75 \%$ dari gangguan endokrin secara keseluruhan (Santosa, 2012).Diabetes Melitus (DM) merupakan salah satu penyakit metabolik yang bersifat kronik yang ditandai dengan hiperglikemia yaitu peningkatan gula darah yang disebabkan adanya kelainan sekresi insulin, resistensi insulin atau keduanya dan dapat mengakibatkan kerusakan jangka panjang serta disfungsi atau kegagalan pada beberapa organ tubuh (Soegondo, 2013). Diabetes Melitus (DM) merupakan penyakit degeneratif yang diperkirakan akan terus meningkat prevalensinya. International Diabetes Federation (IDF) menyatakan bahwa penderita penderita diabetes yang berumur 20-79 tahun berjumlah lebih dari 371 juta orang di dunia. Sedangkan Indonesia merupakan negara dengan prevalensi diabetes tertinggi urutan ke-7 di bawah China, India, USA, Brazil, Rusia dan Mexico. Prevalensi nasional diabetes melitus berdasarkan Riskesdas, (2013) adalah sebesar $1,1 \%$ (berdasarkan diagnosis tenaga kesehatan dan gejala) dan sebanyak 17 provinsi mempunyai prevalensi penyakit diabetes melitus diatas prevalensi nasional, yaitu dengan wilayah tertinggi terdapat di Sulawesi Tengah (3,7\%), Sulawesi Utara $(3,6 \%)$, Sulawesi Selatan $(3,4 \%)$, Nusa Tenggara Timur $(3,3 \%)$, DIY $(2,6 \%)$, DKI Jakarta n (2,5\%), Kalimantan Timur (2,3\%), Jawa Timur (0,6\%) dan Jawa Barat (0,5\%). DM berdasarkan sifat penyakitnya yang kronik dapat mengenai seluruh bagian tubuh, sehingga memerlukan pendekatan multidisipliner. Penderita Diabetes Melitus membutuhkan penanganan secara holistik dan integratif, tidak hanya penanganan secara medis tetapi lebih kepada perubahan gaya hidup yang menuntut penderita untuk beradaptasi secara keseluruhan dan mengatur manajemen diri (self management) dengan baik. Program yang diselenggarakan oleh BPJS Kesehatan ini bertujuan untuk mendorong peserta penyandang penyakit kronis dapat mengelola kesehatan (self management) untuk mencapai kualitas hidup optimal. Tujuan penelitian ini untuk mengetahui hubungan antara Self Management dengan Kualitas Hidup Pasien Diabetes Melitus Type 2 di Dusun Sonosewu Kasihan Bantul Yogyakarta. Self Management menggambarkan perilaku individu yang dilakukan secara sadar, bersifat universal dan terbatas pada dirinya sendiri (Sulistria, YM. 2013). Menurut Yudianto (2008) kualitas hidup merupakan perasaan puas dan bahagia sehingga pasien diabetes melitus dapat menjalankan kehidupan sehari-hari dengan semestinya. Salah satu penyakit kronis yang dikelola adalah Diabetes Melitus Tipe 2. Hipotesis dalam penelitian ini hubungan antara Self Management dengan Kualitas Hidup Pasien Diabetes Melitus Type 2.

\section{METODE PENELITIAN}

Jenis penelitian ini adalah deskriptif korelasi yang menghubungkan antara Self Management dengan Kualitas 
Hidup Pasien Diabetes Melitus Type 2 dengan metode penelitian crossectional dilakukan pada waktu yang sama tidak ada periode follow up.Populasi dalam penelinitian ini adalah warga dusun Sonosewu yang menderita DM sebanyak 40 orang. Teknik sampling yang digunakan dalam penelitian ini adalah total sampling.

Instrumen yang digunakan The Summary of Diabetes Self-Care Activities(SDSCA) yang dikembangkan oleh Toobert, D.J et al, (2000) untuk mengetahui self management penderita DM Type 2 yang berisi 14 pertanyaan dan sudah pernah digunakan oleh Kusniawati (2011) dalam penelitiannya dengan judul Analisis Faktor yang Berkontribusi Terhadap Self Care Diabetes pada Klien Diabetes Melitus Tipe 2 di Rumah Sakit Umum Tangerang. Jakarta : Universitas Indonesia. Untuk mengukur kualitas hidup menggunakan instrumen Diabetes Quality of Life (DQOL) yang dikembangkan oleh National Institute of Diabetes and Digestive and Kidney Disease dan sudah pernah digunakan oleh Tyas (2008) dalam penelitian dengan judul Hubungan Perawatan Diri dan Persepsi Sakit dengan Kualitas Hidup Pasien Diabetes Melitus Di Kota Blitar.

\section{HASIL DAN PEMBAHASAN}

\section{HASIL}

Gambaran karakteristik responden diambil berdasarkan usia, jenis kelamin, pendidikan,lama DM dan pekerjaan.
Tabel 1.Karakteristik Responden Penelitian

\begin{tabular}{|c|c|c|}
\hline Karakteristik & $f(x)$ & $\%$ \\
\hline \multicolumn{3}{|l|}{ Usia } \\
\hline Lansia Awal (46-55 tahun) & 7 & 17.5 \\
\hline Lansia Akhir (56-65 tahun) & 22 & 55.2 \\
\hline Masa Manula (> 65 tahun) & 11 & 27,5 \\
\hline \multicolumn{3}{|l|}{ Jenis Kelamin } \\
\hline Perempuan & 29 & 72,5 \\
\hline Laki-laki & 11 & 27,5 \\
\hline \multicolumn{3}{|l|}{ Pendidikan } \\
\hline SD & 11 & 27.5 \\
\hline SMP & 9 & 22,5 \\
\hline SMA & 17 & 42,5 \\
\hline \multicolumn{3}{|l|}{$\frac{\text { PT }}{\text { Lama DM }}$} \\
\hline $1-5$ tahun & 7 & 175 \\
\hline 6-10 tahun & 12 & 30.2 \\
\hline 11-15 tahun & 14 & $35, Q$ \\
\hline lebih dari 15 tahun & 7 & 17,5 \\
\hline \multicolumn{3}{|l|}{ Pekerjaan } \\
\hline PNS & 3 & 7.5 \\
\hline Swasta & 4 & $10 . Q$ \\
\hline Wiraswasta & 6 & $15 . Q$ \\
\hline Buruh & 27 & 67.5 \\
\hline Jumlah & 40 & 100 \\
\hline
\end{tabular}

Berdasarkan tabel 1 karakteristik responden berdasarkan usia didapatkan data sebagian besar berusia 56-65 tahun sejumlah 22 orang (55\%). Berdasarkan patogenesis DM, proses pertambahan usia tersebut juga beresiko terhadap terjadinya DM atau disebut 
prediabetes yaitu kondisi gula darah pasien mengalami gangguan toleransi (140-199 mg/dL). Apabila kadar gula darah mencapai $\geq 200 \mathrm{mg} / \mathrm{dL}$ maka pasien sudah tergolong diabetes melitus. Wulansari \& Isfandiari (2013) menyatakan bahwa pertambahan usia mengakibatkan kemampuan kerja insulin sebagai kunci untuk memasukkan glukosa ke dalam sel sudah tidak berfungsi dengan baik, sehingga terjadi resistensi insulin.Semakin usia lanjut maka kemampuan untuk berfikir, mengambil keputusan akan semakin menurun. Karakteristik responden berdasarkan jenis kelamin didapatkan data sebagian besar responden berjenis kelamin perempuan yaitu sejumlah 29 orang $(72,5 \%)$ dan pasien yang berjenis kelamin laki-laki sebanyak 11 orang (27,5\%). Perempuan lebih beresiko terkena DM karena perempuan memiliki sindroma siklus bulanan (premenstrual syndrome), serta pasca menopouse yang membuat terakumulasinya distribusi lemak tubuh (Irawan, 2010). Berdasarkan penelitian Haryati (2004), jumlah lemak pada perempuan lebih banyak daripada laki-laki yaitu sekitar 20 $25 \%$, sehingga peningkatan kadar lipid dalam darah pada perempuan lebih tinggi dibandingkan laki-laki sehingga menyebabkan perempuan menjadi 3 - 7 kali lebih rentan mengalami DM dibandingkan laki-laki. Pada data karakteristik responden menunjukkan sebagian besar responden memiliki pendidikan SMA sebanyak 17 orang (42,5\%). Tingkat pendidikan berpengaruh terhadap pengetahuan individu dalam penatalaksanaan DM. Pengetahuan akan berpengaruh terhadap keyakinan individu dan dalam pengambilan keputusan.Tingkat pendidikan mempengaruhi perilaku seseorang dalam mencari perawatan atau pengobatan penyakit yang dideritanya dan mampu memilih serta memutuskan tindakan yang akan dijalani untuk mengatasi masalah kesehatannya (Yusra, 2011). Robin (2000) mengungkapkan bahwa seseorang dengn pendidikan tinggi atau lebih cenderung memiliki kualitas hidup lebih baik dari pada yang berpendidikan rendah. Hal ini juga sesuai dengan hasil penelitian yang dilakukan Poradzisz (2001) bahwa 
pasien DM dengan pendidikan rendah memiliki skor kualitas hidup yang rendah. Sebagian besar responden menderita DM yaitu 11 - 15 tahun sebanyak 14 orang $(35,0 \%)$. Hal ini menunjukkan bahwa responden telah memiliki paparan pengetahuan tentang DM yang lebih baik sehingga akan mempengaruhi individu dalam mengambil keputusan dalam manajemen terapeutiknya. Lamanya menderita DM tipe 2 juga dapat memberikan efek negatif terhadap kepatuhan pasien, dimana semakin lama pasien mengidap penyakit, maka semakin kecil pasien patuh terhadap pengobatannya (Asti, 2006). Lama seseorang yang menderita diabetes mellitus tergantung pada bagaimana seseorang tersebut dapat mengontrol kadar gula darahnya karena penyakit diabetes mellitus tidak dapat disembuhkan namun, hanya dapat dikendalikan dengan melakukan perawatan seumur hidup (Soegondo, 2013). Sebagian besar responden bekerja sebagai buruh dan tidak bekerja sebanyak 27 orang $(67,5 \%)$.

\begin{tabular}{|c|c|c|}
\hline Tahel T Nictrihuci & \multicolumn{2}{|c|}{ Frekmenci } \\
\hline Self Management & $f(x)$ & $\%$ \\
\hline Kluang & 14 & 35,0 \\
\hline Cuklup) & 25 & 62,5 \\
\hline Baik & 1 & 2,5 \\
\hline Jumlah & 40 & 100 \\
\hline
\end{tabular}

Berdasarkan tabel 2 didapatkan hasil sebagian besar Self management dalam kategori cukup yaitu sebanyak 25 orang (62,5\%). Pasien Diabetes Melitus Type 2 yang memiliki self management yang baik hanya 1 orang $(2,5 \%)$. Self management merupakan sebuah proses yang tidak hanya berkembang dari waktu ke waktu, tetapi juga berkembang dalam kaitannya dengan jenis pengalaman penyakit seseorang dan masalah spesifik tentang kesehatan (Lin, 2008). Pengelolaan diri tersebut sangat berpengaruh terhadap proses dan hasil pengelolaan penyakit DMT2. Tujuan Self Management adalah untuk mencapai pengontrolan glukosa darah secara optimal serta mencegah terjadinya komplikasi,karena Self Management memiliki peranan penting dalam meningkatkan kualitas kesehatan 
dan kesejahteraan penderita DMT2 (Sulistria, YM, 2013). Self Management merupakan modal perawatan yang paling tepat untuk seseorang yang menderita penyakit kronik seperti diabetes melitus. Self Management pada pasien diabetes melitus merupakan sesuatu yang sangat penting sebab berperan sebagai pengontrol penyakit dan pencegah terjadinya komplikasi (Sigurdardottir, 2005).MenurutSigurdardottir

Self Management pada pasien DM terfokus pada lima aspek yaitu memonitoring kada glukosa darah,perencanaan makan setiap hari,pengaturan terapi,serta latihan fisik secara regular. Sebagian besar pasien DM tipe 2 di Dusun Sonosewu melakukan sel management yang cukup. Hal ini disebabkan karena sebagian besar pasien DM mengikuti kegiatan dan pemeriksaan di posyandu lansia yang dilaksanakan setiap bulan sekali yang disertai dengan kegiatan senam diabetik atau senam lansia. Ditemukan data bahwa sebagian besar pasien DM tipe 2 di Dusun Sonosewu tidak melakukan perawatan kaki. Setelah dilakukan pengkajian dengan

cara wawancara didapatkan hasil bahwa sebagian besar pasien DM tipe2 tidak tahu bagaimana perawatan kaki. Pengelolaan DM saat ini tidak hanya dilakukan oleh dokter, perawat dan tim kesehatan yang lain tetapi pasien juga merupakan tim dalam pengelolaan DM yang akhirnya disebut sebagai perawatan diri (self management/self care). Self management atau Self care yang dilakukan terdiri dari perencanaan diet, aktifitas, terapi DM, pemeriksaan gula darah secara mandiri dan perawatan kaki (Soegondo, 2013)

Tabel 3 Distribusi Frekuensi Karakteristik Kualitas Hidup Pasien

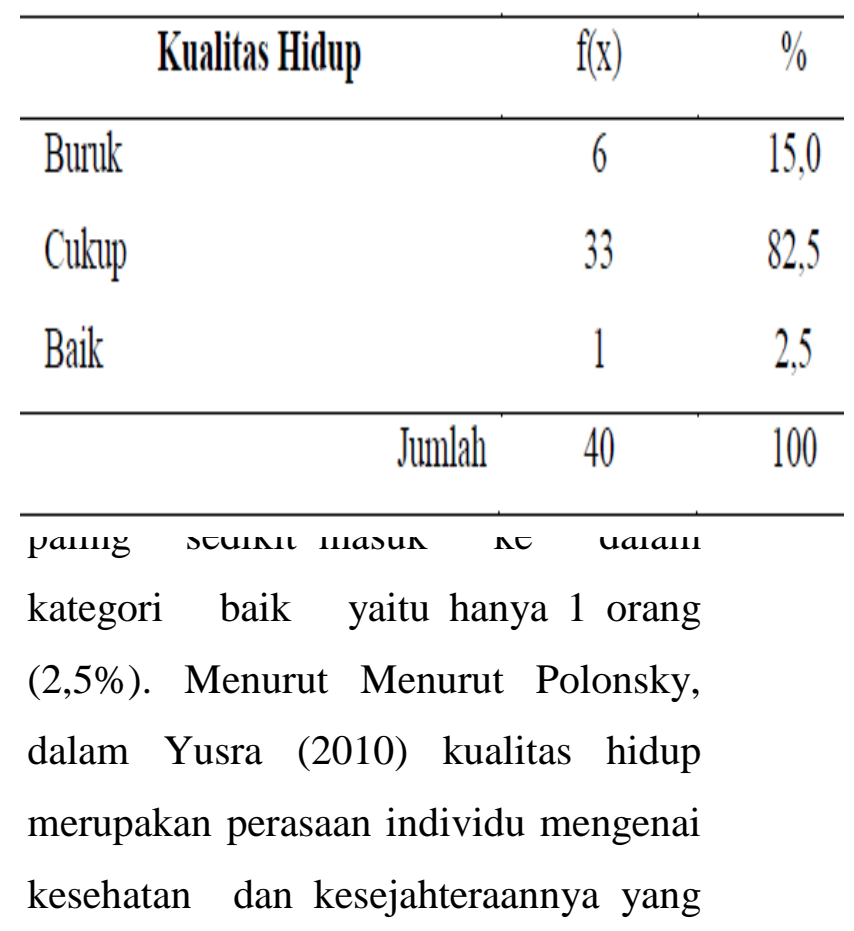


meliputi fungsi fisik, fungsi psikologis dan fungsi sosial. Kualitas hidup dapat diartikan sebagai derajat seorang individu dalam menikmati hidupnya yang terdiri dari kepuasan dan dampak yang dirasakan seorang individu dalam menjalankan kehidupanya sehari-hari (Weissman et all,dalam Yusra,2010). Hasil penelitian ini menunjukkan bahwa sebagian besar pasien DM merasa puas dengan aktifitas pekerjaan dan rumah tangga serta hubungan sosial dan persabatan, dan sebagian besar pasien merasa tidak puas dengan tidur dan diet yang dilakukan setiap harinya. Hal ini sejalan dengan penelitian yang dilakukan oleh Chaidir R, Wahyuni A, Furkhani D (2017) dengan hasil antara self care dengan kualitas hidup pasien diabetes melitus di wilayah kerja Puskesmas Tigo Baleh kualitas hidup responden yang menderita Diabetes Melitus di wilayah kerja Puskesmas Tigo Baleh diukur menggunakan di kuesioner The Diabetes Quality of Life Brief Clinical Inventory. Kuesioner kualitas hidup tersebut terdiri dari kepuasan, dampak, dan kekhawatiran. Hasil yang peneliti peroleh yaitu, dari pernyataan tentang kepuasan responden terhadap diabetes melitus yang dideritanya, pernyataan yang banyak memiliki jawabanya kepuasan terhadap lama waktu yang digunakan dalam mengelola diabetes tersebut dan ketidak puasan dalam tidur sehingga memiliki kualitas tidur yang buruk.

Tabel 4 Hubungan antara Self Management dengan Kualitas Hidup

\begin{tabular}{|c|c|c|c|c|c|c|c|c|c|c|}
\hline \multirow{3}{*}{$\begin{array}{c}\text { Self } \\
\text { Management }\end{array}$} & \multicolumn{8}{|c|}{ Kualitas Hidup } & \multirow[t]{2}{*}{ r } & \multirow[t]{2}{*}{ Pvalue } \\
\hline & \multicolumn{2}{|c|}{ Kurang } & \multicolumn{2}{|c|}{ Cukup } & \multicolumn{2}{|c|}{ Baik } & \multicolumn{2}{|c|}{ Total } & & \\
\hline & $\mathrm{N}$ & $\%$ & $\mathrm{~N}$ & $\%$ & $\mathrm{~N}$ & $\%$ & $\mathrm{~N}$ & $\%$ & 0 , & $0,002 *$ \\
\hline Kurang & 5 & 12. & 9 & 2 & 0 & 0 & 14 & 35,0 & 49 & \\
\hline & & 5 & & $\begin{array}{l}2 \\
5\end{array}$ & & & & & 4 & \\
\hline Cukup & 1 & 2 & 2 & 6 & 0 & 0 & 25 & 62.5 & & \\
\hline Baik & 0 & 0 & 0 & 0 & 1 & 2 & 1 & 2,5 & & \\
\hline Total & 6 & 15 , & 3 & 8 & 1 & 2 & 40 & 100 & & \\
\hline
\end{tabular}

* Bermakna/signifikan pada $\alpha<0,05$

Berdasarkan tabel 4 didapatkan hasil uji antara variabel self management dan variabel kualitas hidup ada hubungan 
Jurnal Kesehatan Karya Husada, No 7 Vol 2 Tahun 2019

PISSN 2337649X/EISSN 2655-8874

Dewi Murdiyanti Prihatin Putri "Hubungan Antara Self Management Dan Kualitas Hidup Pasien

Diabetes Melitus Type 2" (hal 230-240)

yang signifikan. Hal ini dibuktikan dengan $\mathrm{p}$ value $=0,002(<$ $0,05)$.

\section{PEMBAHASAN}

Hubungan yang ditunjukkan adalah positif dengan nilai koefisien korelasi sebesar 0,494, hal ini menunjukkan bahwa hubungan antara self management dengan kualitas hidup berbanding lurus. Korelasi ini menunjukkan bahwa semakin self management pasien Diabetes Melitus Type 2 baik, maka semakin baik pula kualitas hidup pasien. Dalam penelitian ini menunjukkan bahwa sebagian besar pasien DM Tipe 2 di Dusun Sonosewu melakukan self management (60\%) cukup dan memiliki kualitas hidup yang cukup (62,5\%). Sehingga dapat disimpulkan bahwa korelasi antara self management dengan kualitas hidup pasien diabetes melitus di Dusun Sonosewu memiliki tingkat korelasi yang sedang. Hasil penelitian ini sesuai dengan penelitian yang dilakukan oleh Poradzisz (2001) terdapat hubungan yang signifikan antara ketaatan melakukan manajemen DM dengan kualitas hidup ( $<<0,001)$.
Ketaatan melakukan manajemen DM akan meningkatkan kualitas hidup. Sesuai dengan konsep yang diungkapkan Dunning (2003) bahwa rendahnya kualitas hidup berhubungan dengan kalalaian dalam melakukan perawatan diri dan kemungkinan ketidakmampuan pasien dalam melakukan perawatan diri. Hal ini juga sesuai dengan hasil penelitian yang dilakukan Chaidir R, Wahyuni A, Furkhani D (2017) yaitu tentang hubungan antara self care dengan kualitas hidup pasien diabetes melitus di wilayah kerja Puskesmas Tigo Baleh memiliki dua hasil yaitu nilai significant (2-tailed) dan nilai koefisien korelasi. Nilai significant (2tailed) antara self care kualitas hidup pasien diabetes melitus di wilayah kerja Puskesmas Tigo Baleh yaitu $0.001(<0.05)$. Nilai ini memiliki makna yaitu terdapat hubungan yang signifikan antara self care kualitas hidup pasien diabetes melitus di wilayah kerja Puskesmas Tigo Baleh. Hasil nilai korelasi korelasi antara self care dengan kualitas hidup pasien diabetes melitus di wilayah kerja Puskesmas Tigo Baleh yaitu sebesar 
0.432 dengan nilai positif. Hasil ini memiliki makna yaitu terdapat hubungan yang berbanding lurus antara self care dengan kualitas hidup pasien diabetes melitus di wilayah kerja Puskesmas Tigo Baleh.

\section{SIMPULAN DAN SARAN}

\section{SIMPULAN}

Berdasarkan hasil penelitian didapatkan bahwa sebagian besar Self management dalam kategori cukup yaitu sebanyak 25 orang (62,5\%). Pasien Diabetes Melitus Type 2 yang memiliki self management yang baik hanya 1 orang $(2,5 \%)$. Sebagian besar kualitas hidup pasien Diabetes Melitus Type 2 termasuk kedalam kategori cukup yaitu sebanyak 33 orang $(82,5 \%)$ dan paling sedikit masuk ke dalam kategori baik yaitu hanya 1 orang $(2,5 \%)$. Hasil uji antara variabel self management dan variabel kualitas hidup ada hubungan yang signifikan. Hal ini dibuktikan dengan $\mathrm{p}$ value $=0,002$ $(<0,05)$. Hubungan yang ditunjukkan adalah positif dengan nilai koefisien korelasi sebesar 0,494, hal ini menunjukkan bahwa hubungan antara self management dengan kualitas hidup berbanding lurus. Korelasi ini menunjukkan bahwa semakin self management pasien Diabetes Melitus Type 2 baik, maka semakin baik pula kualitas hidup pasien.

\section{DAFTAR PUSTAKA}

Asti. (2006), Kepatuhan Pasien : Faktor Penting Dalam Keberhasilan Terapi, Info POM, Volume 7, Nomor 5, Badan POM RI, Jakarta.

Chaidir R, Wahyuni A, Furkhani D (2017). Hubungan antara Self Care dengan Kualitas Hidup Pasien Diabetes Melitus. Journal Endurance 2 (2) Juni 2017

Dunning, T. (2003). Care of People with Diabetes: A manual of nursing, $2^{\text {nd }}$ ed. Malden Blackwell Publishing.

Haryati, E., (2004). Hubungan Faktor Resiko Umur, Jenis Kelamin, Kegemukan dan Hipertensi Dengan Kejadian DIabetes Melitus Tipe 2 di Wilayah Kerja Puskesmas. Jelantik 
Jurnal Kesehatan Karya Husada, No 7 Vol 2 Tahun 2019

PISSN 2337649X/EISSN 2655-8874

Dewi Murdiyanti Prihatin Putri “Hubungan Antara Self Management Dan Kualitas Hidup Pasien

Diabetes Melitus Type 2" (hal 230-240)

IGMG.Gramedia

Pustaka:Jakarta.

Irawan, Dedi. (2010). Prevalensi dan

Faktor Resiko Kejadian

Diabetes Melitus Tipe 2 di

Daerah Urban Indonesia

(Analisis Data Sekunder

Riskesdas, 2007). Thesis

Universitas Indonesia.

Kusniawati. (2011). Analisis Faktor yang Berkotribusi terhadap Self Care Diabetes pada

Klien Diabetes Melitus Tipe 2

di Rumah Sakit Umum

Tanggerang . FIK. UI

Poradzisz,M. (2001) Variables Affecting quality of life and adherence in adults with

Sigurdardottir, A. K. (2005). Self-Care in Diabetes: Model of Factors Affecting Self-Care. Jurnal of Clinical Nursing,301-314.

Soegondo,S. (2013). Diagnosis dan klasifikasi diabetes mellitus terkini. Dalam S. Soegondo, P. Soewondo, \& I.Subekti (Editor), Penatalaksanaan Diabetes Mellitus Terpadu : type 2 diabetes, http:proquest.umi.com/pqdwe b? in dex $=80 \&$ did. Riskesdas. (2013). Riset Kesehatan Dasar. Jakarta.

Rubin, R.R (2000) Diabetes and Quality of Life. Diabetes Spectrum 13, http://journal.diabetes.org/dia betes spectrum/00v13n1/pq21htm.

Santosa, B. (2012). Gangguan Endokrin sebabkan Banyak Penyakit. Dalam Simposium Ilmiah Perkembangan

Endokrin, Diagnosa dan Terapi. RS Gading Pluit Jakarta.

Panduan Penatalaksanaan Diabetes Mellitus bagi Dokter dan Edukator ( hal 19-29). Jakarta: FKUI.

Sulistria,Y.M., (2013). Tingkat Self Care pada pasien rawat jalan Diabetes Melitus di Puskesmas Kalirungkut Surabaya. Jurnal Ilmiah 
Jurnal Kesehatan Karya Husada, No 7 Vol 2 Tahun 2019

PISSN 2337649X/EISSN 2655-8874

Dewi Murdiyanti Prihatin Putri 'Hubungan Antara Self Management Dan Kualitas Hidup Pasien

Diabetes Melitus Type 2" (hal 230-240)

Mahasiswa Universitas

Surabaya Vol.2. Surabaya.

Toobert, D.J., Hampson, S.E \& Glasgow, R.E (2000) The Summary of Diabetes Self Care Activities Measure. Diabetes Care, 23,943950.

Tyas (2008). Hubungan Perawatan Diri danPersepsi Sakit dengan Kualitas Hidup Pasien Diabetes Melitus Di Kota Blitar.Tesis tidak diterbitkan. Jakarta;UI.

Wulandari, Y.M. \& Isfandiari, A.M. (2013). Kaitan Sindroma Metabolik dan Gaya Hidup dengan Gejala Komplikasi Mikrovaskuler. Jurnal Berkala Epidemiologi. Vol.1, No. 2.

Yudianto, Kurniawan, et all. (2008). Kualitas Hidup Penderita Diabetes Melitus Di Rumah Sakit Umum Daerah Cianjur. jurnal Keperawatan, 76.
Yusra, A. (2011). Hubungan Antara Dukungan Keluarga dengan Kualitas Hidup Pasien Diabetes Melitus Tipe 2 di Poliklinik Penyakit Dalam Rumah Sakit Umum Pusat Fatmawati Jakarta. Tesis tidak diterbitkan. Jakarta;UI. 